\title{
Design of drinkable tap water system at X Apartment, Jakarta
}

\author{
Hariastuti Prameswari ${ }^{1}$, Tazkiaturrizki ${ }^{1}$, and Ratnaningsih $\mathrm{R}^{1 . *}$ \\ ${ }^{1}$ Trisakti University, Environmental Engineering, Faculty of Landscape Architecture and Environmental Technology, Jakarta 11440 , \\ Indonesia
}

\begin{abstract}
This design aims to contrive a plumbing system X Apartment, Jakarta with a separate clean water and drinking water system. Water supply system that applied to this apartment is roof tank system. Fluctuations in the use of clean water are used to determine the capacity of reservoirs and pumps using the equivalent apartments such as The Bellagio Residence Apartment, Four Winds Apartment, Tamansari Sudirman Apartment, and Setiabudi Residence Apartment. Total demand for clean water for the $1^{\text {st }}$ and $2^{\text {nd }}$ tower is $315.8 \mathrm{~m}^{3} /$ day and $39 \mathrm{~m}^{3} /$ day for drinking water with $216 \mathrm{~m}^{3}$ of ground water tank capacity. Transfer pumps work for 12 hour/day and the capacity of clean water roof tank for the $1^{\text {st }}$ and $2^{\text {nd }}$ tower are $67.5 \mathrm{~m}^{3}$ while for drinking water roof tank are $7.2 \mathrm{~m}^{3}$. System that has been chosen used 2 stand pipes for both clean water, drinking water, and booster pumps in each tower. This design concluded that The investment cost of clean water and drinking water system and also the construction of $\mathrm{X}$ Apartment reservoirs is $\mathrm{Rp}$. 2.393.889.860 and the cost of drinking water that can be saved by residents when using drinkable tap water system is Rp. 874.656 per $\mathrm{m}^{3}$.
\end{abstract}

\section{Introduction}

The apartments are rated as practical residence for the community especially those located in big cities such as Jakarta, both as permanent residence or as stopover place. A good apartment should be able to provide clean water. To provide water with good quality and quantity it needs a good plumbing system as well. Plumbing system is an inseparable part of building construction. Therefore, planning and design of the plumbing system should be carried out simultaneously and in accordance with the stages of planning and design of the building itself, with careful attention to its relationship with parts of the building construction as well as with other equipment in the building.

In Indonesia there's not many buildings that provide a drinkable tap water. XYZ Apartment is planned to provide the drinkable tap water to increase the sale value of this apartment, save costs for drinking water needs (bottled water), and minimize plastic water residues. Drinking water will be obtain from clean water treated using reverse osmosis membrane technology then will be provide on every sink.

According to Peraturan Menteri Kesehatan RI No. 492/MENKES/PER/IV/2010 [1], drinking water is water which processed or without processing that fulfill health requirement and can be directly drunk. In the technical guidance [2], it is written that the human need for water starts with the needs of drinking water to the needs of sanitation. For the needs of human drinking water itself requires 10 liters/person/day. Thus, the need for drinking water to be consumed (drinking water and cooking) requires 10-30 liters/person/day. The provision of drinking water should pay attention to the source of drinking water, water quality, and quantity [3].

\section{Methods}

One of the apartments that being planned is $\mathrm{XYZ}$ Apartments which located on Jl. Prof. DR. Satrio No. 7, Karet Kuningan, Jakarta. This apartment will be built on area of $5.720 \mathrm{~m}^{2}$ with a building area of $\pm 34.000 \mathrm{~m}^{2}$ with two apartment towers. The $1^{\text {st }}$ apartments will stand as high as 32 floors and the $2^{\text {nd }}$ tower with 35 floors. This apartment consist 23 floors of residential for the $1^{\text {st }}$ tower and 26 floors for the $2^{\text {nd }}$ tower because the top three floors are owned by the $2^{\text {nd }}$ tower only. Types of occupancy that contained in this apartment is the Studio type, 1 Bedroom type, and 2 Bedroom type. This apartment uses a water source from PAM and will deliver its waste water through PD PAL.

Stages of planning at XYZ Apartment consist of determine the location and planning time. Then, collecting primary data and secondary data. Primary data is fluctuations measurement in water consumption from the comparative apartments and secondary data is the floor plan and land area from the masterplan. Data analysis consist of planning the clean water and drinking water system. Fluctuation in the use of water obtained from comparable apartments taken from Bellagio Residence Apartment, Four Winds Apartment, Tamansari Sudirman Apartment, and Setiabudi Residence Apartment and will be used as references to design the reservoir capacity. Calculating the need for

* Corresponding author: ratnaningsih@trisakti.ac.id 
clean water and drinking water is obtained by the following formula [4]:

$$
\begin{gathered}
\mathrm{Q}_{\text {day }}=\Sigma \text { Population (person) } \mathrm{x} \text { Water demand } \\
\text { (liter/person/day) }
\end{gathered}
$$

The population and water requirements of the comparative apartment used to determine the water demand of designed apartment. Wastewater generated ranges from $80 \%$ to $90 \%$ of clean water [5]. The reservoir capacity is obtained trough fluctuations in water consumption from comparative apartment which is the most typical with designed apartment. The capacity of transfer and booster pumps is determined through the needs of clean water and drinking water of XYZ Apartments. Then, calculating the investment cost for clean water and drinking water pipes, accessories, pumps, reservoir, and saving on drinking water cost.

\section{Results and discussion}

\subsection{Clean and drinking water system}

The water supply system used a roof tank system. Clean water from PAM is supplied continuously for 24 hours and collected firstly in ground water tank (GWT), then it will be transferred using a transfer pump to the clean water roof tank (RT), then distributed to each plumbing equipment in each residential units and facilities by gravitation. In general, apartments only provide clean water but XYZ Apartment is designed to provide drinkable tap water. Potable water will be processed by using membrane technology (reverse osmosis) and then collected first in on the drinking water roof tank before being distributed to each sink in the kitchen or bathroom or restroom facilities by using booster pump on several top floors. On certain floors also installed pressure reducing valve (PRV) to ensure the connection does not exceed the maximum limit of the pipes.

This design criteria is used as the basis for determining and calculating components in drinking water system based on quality standard DIN 8077 8078 and ISO $9001: 2000$. The type of pipe used for the provision of clean water is PP-R type PN 10 which is a pipe can withstand high pressure up to 10 bar. Basically PP-R pipes have been declared as material with food grade category so it is safe to use on drinking water system.

The number of stand pipes that used in this design are 2 clean water stand pipes and 2 drinking water stand pipes that are distributed by gravitation. And there are 2 clean water stand pipes and 2 drinking water stand pipes using booster pumps. The $1^{\text {st }}$ tower uses booster pumps on the top 10 floors for clean water and top 11 floors for drinking water as for the $2^{\text {nd }}$ tower use top 9 floors for both clean and drinking water. There are 4 PRVs installed on each stand pipe.

\subsection{Fluctuation of clean water consumption}

Fluctuation data were taken from the comparative apartments with the designed apartment such as The Bellagio Residence Apartment, Four Winds Apartment, Tamansari Sudirman Apartment, and Setiabudi Residence Apartment. Fluctuation data of clean water consumption od Tamamsari Sudirman Apartent and Setiabudi Residence Apartment was obtained from previous design by [6] and [7] while two other apartments were done by direct measurement. Measurement of fluctuation of clean water consumption in The Bellagio Residence Apartment and Four Winds Apartment is done through the water meter of each unit for 6 weekdays and 2 weekends. The data obtained are in units of $\mathrm{m}^{3}$ per hour and then the percentage of clean water consumption per hour in one day and the average percentage of water consumption during the weekdays and weekend can be calculated. After that, fluctuation of clean water consumption from comparison apartments will be selected which most typical with the designed apartment. The chosen fluctuation data is from The Belllagio Residence Apartments because it is the most typical with the designed apartment such as its lifestyle, residents, and also the location that is located in central business district area. Fluctuation data on weekdays and weekend can be seen in Fig. 1

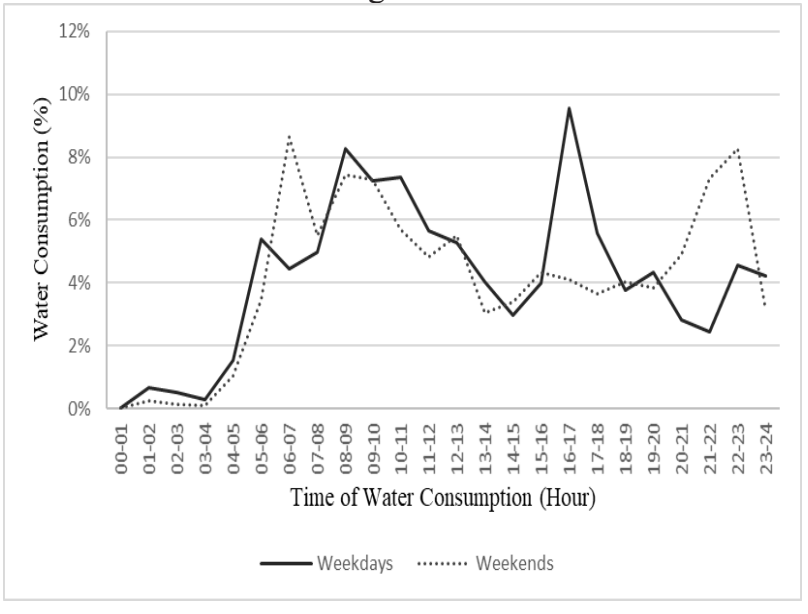

Fig. 1. Fluctuation of The Bellagio Residence.

\subsection{Clean and drinking water needs}

The water needs in three apartments (The Bellagio Residence Apartment, Four Winds Apartment, and Tamansari Sudirman Apartment) per day is $509.13 \mathrm{~m}^{3}$ of the total occupants are 2092 people so the water consumption is 243.4 liter per person per day. The data from Setiabudi Residence Apartment is excluded because it does not have data on the number of occupants. The data of water consumption and the amount of water needed for the apartment is needed to determine the reservoir volume. The water requirement of XYZ Apartment is divided into the needs of clean water and drinking water. Based on fluctuation data of $\mathrm{XYZ}$ Apartment water usage, the need for clean water is $315.8 \mathrm{~m}^{3} /$ day and drinking water is $39 \mathrm{~m}^{3} /$ day. The water balance of XYZ Apartment can be seen in Fig. 2 


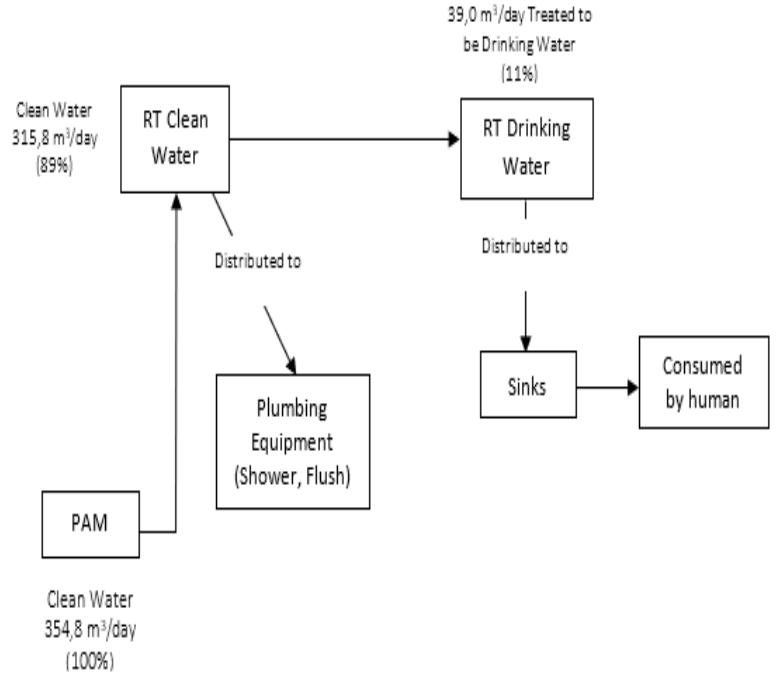

Fig. 2. Water Balance of XYZ Apartment.

\subsection{Reservoir capacity}

In the design of XYZ Apartment, water pumped to roof tank for 12 hours with 3 different time frames to obtain the most efficient result, pumping without pause, one pause, and two pauses. On weekdays and weekends the most efficient time is 12 hours of pumping with one pause starting at $05.00-11.00$ and $15.00-21.00$ with efficiency of $19.91 \%$ for weekdays and $25.07 \%$ on weekends. The pump used is booster pump Grundfos CR 5-10 $50 \mathrm{~Hz}$ Number 96518431 and Grundfos CR 5-8 $50 \mathrm{~Hz}$ Number 96518450 , while for drinking water use Grundfos CR 1-7 50 Hz Number 96515357.

The result shows that the highest percentage value of fluctuation in water consumption occurs on weekend, so the upper reservoir volume is determined based on the percentage of weekend. Consideration in choosing a large percentage in order to meet the needs of water at the time of maximum needs. After calculating the fluctuation percentage data on weekends, the reservoir volume can be determined.

The ground reservoir for clean water is on the semibasement floor. Determination of ground reservoir capacity through water supply from PAM for 24 hours. Determination of its use based on water pumping from the ground reservoir to roof reservoir for 12 hours. On the rooftop there is a roof reservoir for both the clean water and drinking water reservoir. The drinking water reservoir is only available on the rooftop because the water treatment from clean water to drinking water is done on the rooftop by using reverse osmosis. The drinking water requirement is $39 \mathrm{~m}^{3}$ per day so it must use reverse osmosis RO 6000 GPD machine type as much as 2 units for each tower which has 700 gallon per day production capacity. Reservoir for drinking water should also be made from food grade material so that the quality of drinking water is maintained before it is distributed to every sink. The pump used as a water transfer pump is a Grundfos CR pump $15-1250 \mathrm{~Hz}$ Number 96501902 with each tower has two pumps, one for the operational and the other as a backup pump.

\subsection{Investment and construction cost plan}

The investment cost plan for drinking water reservoir with food grade material with price per $\mathrm{m}^{3}$ is $\mathrm{Rp}$. 2.669.137 and required 2 drinking water reservoir with volume of each is $7.2 \mathrm{~m}^{3}$. For clean water reservoir planned is reservoir panel with knock down installation system by using fiber glass material with price per $\mathrm{m} 3$ is Rp. 2.650.000 required 2 clean water reservoir with volume for each is $67.5 \mathrm{~m}^{3}$. Meanwhile, the ground reservoir volume is $216 \mathrm{~m}^{3}$. Ground reservoir is constructed with concrete frames at prices based on Standardization of Construction Work Unit Planning of DKI Jakarta Province (2014) [8]. That way, the total cost required to make the roof and ground reservoir is $\mathrm{Rp}$. 1.401.156.427.

After budget plan calculation of investment cost of clean water pipe and its accessories is Rp. 528.113.609 and for drinking water pipe and its maintenance is Rp. 528.619.824. It is known that the price of drinking water supply system is Rp. 528.619 .824 with $39 \mathrm{~m}^{3}$ per day of water requirement. If the investment price is expected to return within 5 years, the water price per $\mathrm{m}^{3}$ is:

$\frac{\text { Rp. } 528.619 .924}{39 \frac{3 l^{3}}{d a y} \times 30 \frac{\text { day }}{\text { monith }} \times 12 \frac{\text { menth }}{\text { yeswr }} \times 5 \text { years }}=$ Rp. 7.530 per $\mathrm{m}^{3}$

Water that used to be drinking water is processed from clean water. In accordance with Jakarta Governor Regulation Number 11/2007 on Automatic Tariff Adjustment, the apartment is included in IV B Group. The water usage in XYZ Apartment exceeds $20 \mathrm{~m}^{3}$ per day so the rate per $\mathrm{m}^{3}$ is Rp. 12.550 So the water price is Rp. 20.080 When using bottled water, the price is $\mathrm{Rp}$. 17.000 per 19 liters, then the price per $\mathrm{m} 3$ is Rp. 894.736 Although it is not commonly used in many countries, in Indonesia drinkable tap water has not been widely use. Although there is already drinkable tap water in public spaces such as airports, there are still many people who doubt the quality and still choose to buy bottled water which is not good for environment.

\section{Conclusions}

Drinkable tap water is a common thing that has been used in different part of the world such as in European Countries. In Indonesia, drinkable tap water is also provided in public spaces such as airports. The price of drinkable tap water per $\mathrm{m}^{3}$ in the apartment is around Rp. 20.080 whereas when buying bottled water, the water price per $\mathrm{m}^{3}$ is $\mathrm{Rp} .894 .736$ so that the residents of XYZ Apartments can save Rp. 874.656 in addition to saving the cost of drinking water, residents can also minimize the use of plastic waste from drinking bottled water. The community needs to be educated about drinkable tap water system so that it can be used optimally. 


\section{References}

1. Minister of Health Republic of Indonesia. Minister of Health Regulation No. 492 on Water Quality Requirements (2010)

2. Director of General Cipta Karya. Technical Guidelines for the Use of the Special Allocation Fund for Infrastructure Sector. Apendix 3A (2007)

3. National Standardization Agency. Indonesian National Standard $8153: 2015$ on Plumbing System in Building (2015)

4. Morimura Takeo and Sofyan M. Noerbambang. Planning and Maintanance of Plumbing System. (PT Pradnya Paramita, Jakarta, 1985)

5. Setiyono. Planning Design of Wastewater Treatment Plant (WWTP) and Reuse Water in Hotel Environment. JAI Vol 5 No. 2. (2009)

6. I Faya W. Design of Plumbing System at Tamansari Excecutive Residence Apartment Kuningan, South Jakarta. Final Project, (Trisakti University Jakarta, Jakarta, 2009)

7. Fahrudin. Design of Plumbing System at Setiabudi Residence Apartment Karet Kuningan, South Jakarta. Final Project, (Trisakti University Jakarta, Jakarta, 2006)

8. Regional Secretary of DKI Jakarta. Standardization of Construction Work Unit of DKI Jakarta Province (2014)

9. https://www.pipajaya.com/harga-pipa-pvc/ accessed on Monday, January $8^{\text {th }}$ (2018) 